\title{
NIEODPLATNA POMOC PRAWNA JAKO INSTRUMENT ZABEZPIECZENIA SPOŁECZNEGO
}

\section{WPROWADZENIE}

Ustawą z 5 sierpnia 2015 r. o nieodpłatnej pomocy prawnej oraz edukacji prawnej ${ }^{1}$ wprowadzono do polskiego porządku prawnego instrument majacy służyć umożliwieniu dostępu do uzyskania porady prawnej osobom, które z uwagi na swój status materialny lub sytuację życiową nie mają możliwości uzyskania profesjonalnej pomocy prawnej. Tak sformułowany cel regulacji prawnej pozwala na zadanie pytania, w jakiej mierze nieodpłatna pomoc prawna może być uznana za instrument zabezpieczenia społecznego.

Aby odpowiedzieć na powyższe pytanie, w pierwszej kolejności należy dokonać analizy przepisów ustawy i ustalić funkcję nieodpłatnej pomocy prawnej przez zbadanie zasad udzielania i zakresu przedmiotowego tej pomocy oraz kręgu osób uprawnionych do jej otrzymania, a także rozwiąań organizacyjno-finansowych oraz ich porównania z regulacjami prawa procesowego dotyczącymi zwolnienia z kosztów sądowych oraz ustanowienia pełnomocnika z urzędu. Następnie omówione zostanie pojęcie „zabezpieczenie społeczne”, aby na tym tle móc ocenić przepisy ustawy.

\section{ZASADY UDZIELANIA NIEODPLATNEJ POMOCY PRAWNEJ}

\section{Zakres przedmiotowy i podmiotowy nieodpłatnej pomocy prawnej}

Przedmiotowa ustawa określa zasady udzielania nieodpłatnej pomocy prawnej. Należy jednak zaznaczyć, że nie zwalnia ona organów administracji publicznej od wykonywania określonych w ustawach zadań w zakresie poradnictwa prawnego (co dotyczy instytucji pomocy społecznej, biur poselskich i senatorskich, Państwowej Inspekcji Pracy, sądów, prokuratur oraz powiatowych rzeczników konsumentów), jak również w żaden sposób nie ogranicza działalności w zakresie nieodpłatnego poradnictwa prawnego (co dotyczy np. organizacji pozarządowych, Studenckich Poradni Prawnych itp.) $)^{2}$. Trzeba

\footnotetext{
${ }^{1}$ Dz. U. z 28 sierpnia 2015 r. (dalej jako: u.n.p.p.).

${ }^{2}$ Zastrzeżenie to ma w istocie charakter formalny, w rzeczywistości bowiem udzielanie nieodpłatnych porad przez profesjonalistów będzie niewątpliwie miało wpływ na funkcjonowanie podmiotów, w których porad udzielają np. studenci.
} 
także zauważyć, że nieodpłatną informację oraz pomoc prawną przewidują również przepisy ustawy z 13 czerwca 2003 r. o udzielaniu cudzoziemcom ochrony na terytorium $\mathrm{RP}^{3}$. Mając jednak na uwadze zakres podmiotowy i przedmiotowy tej ustawy, można pominać ją w ramach niniejszego opracowania.

$\mathrm{Z}$ punktu widzenia omawianej problematyki istotne znaczenie mają natomiast postanowienia ustawy o nieodpłatnej pomocy prawnej dwojako ograniczające jej udzielanie.

Ustawa przewiduje w pierwszej kolejności ograniczenia przedmiotowe. Zgodnie z art. 3 ust. 1 u.n.p.p. nieodpłatna pomoc prawna obejmuje: 1) poinformowanie osoby uprawnionej o obowiąującym stanie prawnym, o przysługujących jej uprawnieniach lub o spoczywających na niej obowiązkach, 2) wskazanie osobie uprawnionej sposobu rozwiązania jej problemu prawnego, 3) udzielenie pomocy w sporządzeniu projektu pisma w sprawach, o których mowa w pkt 1 i 2 , z wyłączeniem pism procesowych w toczacym się postępowaniu przygotowawczym lub sądowym i pism w toczącym się postępowaniu sądowoadministracyjnym, 4) sporządzenie projektu pisma o zwolnienie od kosztów sądowych lub ustanowienie pełnomocnika z urzędu w postępowaniu sądowym lub ustanowienie adwokata, radcy prawnego, doradcy podatkowego lub rzecznika patentowego w postępowaniu sądowoadministracyjnym. Zakres pomocy jest zatem stosunkowo waski i ogranicza się do stadium przedsądowego. Jednocześnie trzeba zauważyć, że art. 3 ust. 2 u.n.p.p. wyłącza z nieodpłatnej pomocy prawnej sprawy: 1) podatkowe związane z prowadzeniem działalności gospodarczej; 2) z zakresu prawa celnego, dewizowego i handlowego oraz 3) związane z prowadzeniem działalności gospodarczej, z wyjątkiem przygotowania do rozpoczęcia tej działalności.

Natomiast w kwestii ograniczeń podmiotowych w art. 4 u.n.p.p. wskazano katalog osób uprawnionych. Przede wszystkim sa to osoby, którym w okresie 12 miesięcy poprzedzających zwrócenie się o udzielenie nieodpłatnej pomocy prawnej zostało przyznane świadczenie z pomocy społecznej na podstawie ustawy z 12 marca 2004 r. o pomocy społecznej ${ }^{4}$ i wobec których w tym okresie nie wydano decyzji o zwrocie nienależnie pobranego świadczenia. Do osób uprawnionych zaliczono także posiadaczy ważnej Karty Dużej Rodziny ${ }^{5}$ oraz osoby, które uzyskały zaświadczenie wskazane w ustawie z 24 stycznia $1991 \mathrm{r}$. o kombatantach oraz niektórych osobach będących ofiarami represji wojennych i okresu powojennego ${ }^{6}$, lub które posiadają ważną legitymację weterana albo legitymację weterana poszkodowanego, o których mowa w ustawie z 19 sierpnia 2011 r. o weteranach działań poza granicami państwa ${ }^{7}$. Kolejne grupy osób uprawnionych określono za pomoca kryterium wieku, wskazując osoby, które nie ukończyły 26 lat lub które ukończyły 65 lat. W ostatnim punkcie do osób uprawnionych zaliczono osoby, które w wyniku wystąpienia klęski żywiołowej, katastrofy naturalnej lub awarii technicznej znalazły się w sytu-

\footnotetext{
${ }^{3}$ Dz. U. 2012, poz. 680 ze zm.

${ }^{4}$ Dz. U. 2015, poz. 163 ze zm.

5 Por. ustawa z 5 grudnia 2014 r. o Karcie Dużej Rodziny, Dz. U. poz. 1863.

6 Dz. U. 2014, poz. 1206 oraz Dz. U. 2015, poz. 693.

7 Dz. U. Nr 205, poz. 1203.
} 
acji zagrożenia lub poniosły straty, przy czym osoby takie swoje prawo do nieodpłatnej pomocy prawnej wykazują przez złożenie oświadczenia, że zachodzi co najmniej jedna z wymienionych okoliczności.

\section{Organizacja i finansowanie udzielania nieodpłatnej pomocy prawnej}

Ustawa stanowi, że udzielanie nieodpłatnej pomocy prawnej jest zadaniem zleconym z zakresu administracji rządowej realizowanym przez powiat $\mathrm{w}$ porozumieniu z gminami albo samodzielnie (art. 8 ust. 1 u.n.p.p.). Jednocześnie przewiduje, że co do zasady nieodpłatnej pomocy prawnej udziela osobiście adwokat lub radca prawny na podstawie umowy zawartej z powiatem (aplikant adwokacki lub aplikant radcowski mogą działać z ich upoważnienia jedynie „w szczególnie uzasadnionych przypadkach” - art. 5 ust. 1 u.n.p.p.). Punktem wyjścia umów zawieranych z poszczególnymi adwokatami i radcami prawnym jest wskazane w art. 10 ust. 1 u.n.p.p. porozumienie zawierane corocznie przez powiat $\mathrm{z}$ okręgową radą adwokacką i radą okręgowej izby radców prawnych właściwymi dla siedziby władz powiatu. W przypadku niezawarcia porozumienia do 30 listopada roku poprzedzającego rok, którego dotyczyłoby to porozumienie, starosta przekazuje dziekanom informacje o gminnych lub powiatowych lokalach, w których będą usytuowane punkty nieodpłatnej pomocy prawnej, oraz harmonogram wskazujacy dni i godziny, w których będzie ona udzielana ${ }^{8}$. Na podstawie tych informacji dziekan okręgowej rady adwokackiej lub dziekan rady okręgowej izby radców prawnych wskazuje odpowiednio adwokatów lub radców prawnych, wyznaczonych do udzielania nieodpłatnej pomocy prawnej (art. 10 ust. 2 u.n.p.p.).

Ponadto ustawa przewiduje, że powiat powierza prowadzenie połowy punktów nieodpłatnej pomocy prawnej organizacji pozarządowej prowadzącej działalność pożytku publicznego, z tym że jeżeli na powiat przypada nie więcej niż trzy punkty nieodpłatnej pomocy prawnej, organizacji pozarządowej powierza się prowadzenie jednego punktu nieodpłatnej pomocy prawnej ${ }^{9}$. Organizację pozarządową wyłania się corocznie w otwartym konkursie ofert, o którym mowa w ustawie z 24 kwietnia 2003 r. o działalności pożytku publicznego i o wolontariacie ${ }^{10}$. O powierzenie prowadzenia punktu nieodpłatnej pomocy prawnej może ubiegać się organizacja pozarządowa, która spełnia łącznie następujące warunki: posiada co najmniej dwuletnie doświadczenie w wykonywaniu zadań wiążących się z udzielaniem porad prawnych lub informacji prawnych; przedstawi zawarte umowy lub promesy ich zawarcia $\mathrm{z}$ adwokatem, radca prawnym, doradca podatkowym lub osoba, o której mowa w ust. 3 pkt 2 (magister prawa z doświadczeniem zawodowym, por. niżej); daje gwarancję należytego wykonania zadania, w szczególności przez złożenie pisemnego zobowiązania zapewnienia poufności w związku z udzielaniem nie-

\footnotetext{
${ }^{8}$ Nieodpłatna pomoc prawna jest udzielana w punkcie nieodpłatnej pomocy prawnej w przeciętnym wymiarze 5 dni w tygodniu przez co najmniej 4 godziny dziennie (art. 8 ust. 2 i 3 u.n.p.p.).

${ }_{9}$ Ustawa przewiduje, że na każdy powiat przypada liczba punktów nieodpłatnej pomocy prawnej odpowiadająca mnożnikowi, o którym mowa w art. 20 ust. 4 u.n.p.p. (por. niżej).

${ }^{10}$ Dz. U. 2014, poz. 1118 ze zm. (dalej jako: u.d.p.p.).
} 
odpłatnej pomocy prawnej i jej dokumentowaniem oraz zapewnienia profesjonalnego i rzetelnego udzielania nieodpłatnej pomocy prawnej, w szczególności w sytuacji, gdy zachodzi konflikt interesów.

Organizacja pozarządowa zapewnia udzielanie nieodpłatnej pomocy prawnej na podstawie umowy zawartej z powiatem, do której stosuje się odpowiednio przepisy art. 6 ust. 2 pkt 1 i 3-6 u.n.p.p. dotyczace umowy zawartej $\mathrm{z}$ adwokatem lub radca prawnym. O ile wyłączenie w odniesieniu do zasad rozwiązania umowy można uznać za usprawiedliwione, gdyż problematykę tę reguluje rozporządzenie wykonawcze do u.d.p.p. ${ }^{11}$, to pominięcie kwestii wynagrodzenia nie jest do końca jasne. Istnieje wprawdzie możliwość udzielania nieodpłatnej pomocy prawnej przez organizację pozarządową na własny koszt, opierającej się na świadczeniach wolontariuszy, niemniej ustawa, określajac podział dotacji na finansowanie nieodpłatnej pomocy prawnej, expressis verbis stanowi, że jest ona przeznaczana w 97\% „na rzecz wyłonionej organizacji pozarządowej” (por. art. 20 ust. 1 u.n.p.p.). Jak się wydaje, uzasadniona jest teza, że określenie wynagrodzenia jest fakultatywnym elementem umowy organizacji pozarządowej z powiatem, a art. 20 ust. 1 u.n.p.p. ma gwarantować, że w przypadku uzgodnienia wynagrodzenia zostanie ono wydatkowane w ustalonych w ustawie proporcjach. Trzeba przy tym wyraźnie podkreślić, że mowa jest tu o wynagrodzeniu organizacji pozarządowej, a nie o wynagrodzeniu adwokata, radcy prawnego, doradcy podatkowego lub osoby, o której mowa w ust. 3 pkt 2 u.n.p.p. W odniesieniu do tych osób ewentualne (możliwe jest bowiem przecież także udzielanie przez te osoby świadczeń nieodpłatnie, pro publico bono) wynagrodzenie określa wskazana w art. 11 ust. 6 pkt 2 u.n.p.p. umowa z organizacją pozarządową. Co ważne: w przypadku niezawarcia przez organizację pozarządową umów z osobą uprawnioną do udzielania nieodpłatnej pomocy prawnej, starosta nie zawiera umowy z taka organizacja pozarządową albo rozwiązuje ją za dwutygodniowym wypowiedzeniem. W razie niespełnienia innych warunków określonych w art. 11 ust. 6 u.n.p.p. starosta może rozwiązać umowę za dwutygodniowym wypowiedzeniem. W przypadku gdy do 30 listopada roku poprzedzającego rok, którego dotyczyłoby powierzenie prowadzenia punktu nieodpłatnej pomocy prawnej, nie zostanie wyłoniona organizacja pozarządowa do jego prowadzenia, względnie starosta nie zawrze umowy z organizacją pozarządową albo rozwiąże umowę za wypowiedzeniem, stosuje się art. 10 ust. 2 u.n.p.p., tzn. przekazuje stosowną informację dotyczaccą lokali oraz dni i godzin udzielania pomocy dziekanom okręgowej rady adwokackiej lub rady okręgowej izby radców prawnych, którzy na tej podstawie wskazują odpowiednio adwokatów lub radców prawnych wyznaczonych do udzielania nieodpłatnej pomocy prawnej.

Jak już wyżej wskazano, w punktach powierzonych do prowadzenia organizacji pozarządowej nieodpłatnej pomocy prawnej mogą udzielać także podmioty inne niż adwokaci lub radcowie prawni. W art. 11 ust. 3 u.n.p.p. mowa jest o doradcy podatkowym (ale tylko w zakresie prawa podatkowego,

11 Por. § 13-15 wzoru umowy o wsparcie/powierzenie realizacji zadania publicznego, stanowiącego załącznik nr 2 do rozporządzenia Ministra Pracy i Polityki Społecznej z 5 grudnia 2010 r. w sprawie wzoru oferty i ramowego wzoru umowy dotyczacych realizacji zadania publicznego oraz wzoru sprawozdania z wykonania tego zadania, wydanego na podstawie art. 19 u.d.p.p. 
z wyłączeniem spraw podatkowych związanych z prowadzeniem działalności gospodarczej) oraz osobie, która łącznie spełnia następujące przesłanki: ukończyła wyższe studia prawnicze i uzyskała tytuł magistra lub zagraniczne studia prawnicze uznane w RP, posiada co najmniej trzyletnie doświadczenie w wykonywaniu wymagających wiedzy prawniczej czynności bezpośrednio związanych ze świadczeniem pomocy prawnej, korzysta z pełni praw publicznych oraz ma pełną zdolność do czynności prawnych, nie była karana za umyślne przestępstwo ścigane z oskarżenia publicznego lub przestępstwo skarbowe. Warto wskazać, że art. 11 ust. 4 u.n.p.p. przewiduje złożenie przez osobę uprawnioną pisemnego oświadczenia, że jest ona świadoma uzyskania nieodpłatnej pomocy prawnej od osoby niebędącej adwokatem, radcą prawnym albo doradca podatkowym.

Gdy chodzi o finansowanie nieodpłatnej (dla osoby uprawnionej) pomocy prawnej, to zgodnie z art. 19 ust. 1 u.n.p.p. zadanie polegające na jej udzielaniu jest finansowane $\mathrm{z}$ budżetu państwa z części będącej w dyspozycji wojewodów przez udzielanie dotacji celowej powiatom. Wysokość dotacji jest iloczynem przyjętej kwoty bazowej (w 2016 r. wynosi ona 5150 zł) oraz mnożnika zależnego od liczby mieszkańców danego powiatu (art. 20 ust. 2-4 u.n.p.p.). Dotacja ta w 97\% jest przeznaczana na wynagrodzenia z tytułu umów z adwokatami lub radcami prawnymi, natomiast $\mathrm{w}$ przypadku powierzenia prowadzenia punktu nieodpłatnej pomocy prawnej organizacji pozarządowej na rzecz tejże organizacji, a w 3\% na pokrycie kosztów obsługi organizacyjno-technicznej zadania (art. 20 ust. 1 u.n.p.p.).

Podsumowując, można wskazać, że wprawdzie udzielanie nieodpłatnej pomocy prawnej jest zadaniem zleconym z zakresu administracji rządowej realizowanym przez powiat (zadaniem publicznym), to jednak ogranicza się ono w istocie do działań organizacyjnych. Polegają one na zawieraniu umów (odpłatnych), na podstawie których powiat powierza podmiotom niepublicznym: adwokatom lub radcom prawnym (tj. co do zasady podmiotom prowadzacym działalność gospodarcza) lub organizacjom pozarządowym prowadzacym działalność pożytku publicznego faktyczne udzielanie pomocy prawnej osobom uprawnionym. Dochodzi zatem do powierzenia wykonywania zadania publicznego, finansowanego ze środków publicznych (dotacja z budżetu), podmiotom niebędacym organami władzy publicznej ${ }^{12}$.

\section{NIEODPLATNA POMOC PRAWNA A PRAWNOPROCESOWE INSTRUMENTY WSPARCIA OSÓB W TRUDNEJ SYTUACJI MATERIALNEJ}

Przy omawianiu zagadnienia funkcji nieodpłatnej pomocy prawnej należy też pokrótce odnieść się do tradycyjnych prawnoprocesowych instrumentów wsparcia osób w trudnej sytuacji materialnej, służących umożliwieniu im

12 Szerzej na ten temat por. D. E. Lach, Powierzanie realizacji zadań publicznych z zakresu zabezpieczenia społecznego podmiotom niepublicznym, „Państwo i Prawo” 2015, z. 2. 
udziału w stadium sądowym przez zwolnienie ich od kosztów sądowych lub ustanowienie nieodpłatnego pełnomocnika. Przechodząc do szczegółów, trzeba wskazać, że w odniesieniu do spraw cywilnych, rodzinnych, prawnopracowniczych oraz z zakresu ubezpieczeń społecznych to ustawa z 28 lipca 2005 r. o kosztach sądowych $\mathrm{w}$ sprawach cywilnych ${ }^{13}$ stanowi, że zwolnienia od kosztów sądowych może się domagać osoba fizyczna, jeżeli złoży oświadczenie obejmujące szczegółowe dane o stanie rodzinnym, majątku, dochodach i źródłach utrzymania osoby ubiegającej się o zwolnienie od kosztów, z którego wynika, że nie jest $\mathrm{w}$ stanie ich ponieść bez uszczerbku utrzymania koniecznego dla siebie i rodziny (art. 102 ust. 1 i 2 u.k.s.c.). Nie zmienia to jednak faktu, że art. 113 ust. 2 pkt 1 u.k.s.c. upoważnia sąd, aby ten, w orzeczeniu kończącym sprawę w instancji, nakazał ściagnąć koszty sądowe nieobciążające przeciwnika (np. dlatego że on także był zwolniony od kosztów) z roszczenia zasadzonego na rzecz strony, której czynność spowodowała ich powstanie. Innymi słowy, zwolniony od kosztów sądowych uczestnik może zostać obciążony nimi w orzeczeniu kończącym postępowanie, jeżeli jednocześnie uzyskał w orzeczeniu środki majątkowe umożliwiające ich pokrycie (por. art. 113 ust. 4 u.k.s.c.) ${ }^{14}$. Kodeks postępowania cywilnego przewiduje nadto, że strona zwolniona przez sąd od kosztów sądowych w całości lub części, może domagać się ustanowienia adwokata lub radcy prawnego (art. $117 \S 1$ k.p.c.). Natomiast osoba fizyczna, niezwolniona przez sąd od kosztów sądowych, może się domagać ustanowienia adwokata lub radcy prawnego, także jeżeli złoży oświadczenie obejmujące szczegółowe dane o swoim stanie rodzinnym, majątku, dochodach i źródłach utrzymania, z którego wynika, że nie jest w stanie ponieść kosztów wynagrodzenia adwokata lub radcy prawnego bez uszczerbku utrzymania koniecznego dla siebie i rodziny (art. $117 \S 2 \mathrm{w}$ zwiazku z art. $117^{1} \S 1$ k.p.c.).

W odniesieniu do spraw karnych Kodeks postępowania karnego stanowi, że sąd lub referendarz sądowy zwalnia osobę w całości lub w części od wyłożenia kosztów podlegających uiszczeniu przy wnoszeniu pisma procesowego, jeżeli wykazała ona, że ze względu na jej sytuację rodzinna, majątkową i wysokość dochodów wyłożenie ich byłoby zbyt uciążliwe (art. 623 k.p.k.), a ustawa z 23 czerwca 1973 r. o opłatach w sprawach karnych ${ }^{15}$ w art. 17 ust. 1 przewiduje, że do zwolnienia od opłat stosuje się odpowiednio przepisy o zwolnieniu od kosztów postępowania karnego. Ponadto zgodnie z art. 78 § 1 k.p.k. oskarżony, który nie ma obrońcy z wyboru, może żądać, aby mu wyznaczono obrońcę z urzędu, jeżeli w sposób należyty wykaże, że nie jest w stanie ponieść kosztów obrony bez uszczerbku dla niezbędnego utrzymania siebie i rodziny.

Natomiast $\mathrm{w}$ odniesieniu do procedury sądowoadministracyjnej ustawa z 30 sierpnia 2002 r. - Prawo o postępowaniu przed sądami administracyjnymi ${ }^{16}$ statuuje „prawo pomocy”, które może być przyznane stronie na jej wniosek (wolny od opłat sądowych) złożony przed wszczęciem postępowania lub w jego

\footnotetext{
${ }^{13}$ Dz. U. 2005, Nr 167, poz. 1398 ze zm. (dalej jako: u.k.s.c.).

${ }^{14}$ Por. A. Górski, L. Walentynowicz, Koszty sqdowe w sprawach cywilnych. Ustawa i orzekanie. Komentarz praktyczny, Oficyna 2008, komentarz do art. 113, Nb. 22-23.

${ }_{15}$ Dz. U. 1973, Nr 27, poz. 152 ze zm.

${ }_{16}$ Dz. U. 2002, Nr 153, poz. 1270 ze zm. (dalej jako: p.p.s.a.).
} 
toku (art. 243 p.p.s.a.). Prawo pomocy obejmuje zwolnienie od kosztów sądowych oraz ustanowienie adwokata, radcy prawnego, doradcy podatkowego lub rzecznika patentowego (art. 244 p.p.s.a.). Podobnie jak w przypadku procedury cywilnej i karnej warunkiem przyznania prawa pomocy osobie fizycznej jest, na mocy art. $246 \S 1$ p.p.s.a., wykazanie przez tę osobę, że nie jest w stanie ponieść żadnych kosztów postępowania (dla pomocy w zakresie całkowitym ${ }^{17}$ ) względnie, że nie jest w stanie ponieść pełnych kosztów postępowania, bez uszczerbku utrzymania koniecznego dla siebie i rodziny (dla pomocy w zakresie częściowym). Zgodnie z art. $252 \S 1$ p.p.s.a. wniosek osoby fizycznej o przyznanie prawa pomocy powinien zawierać oświadczenie obejmujace dokładne dane o stanie majątkowym i dochodach, o stanie rodzinnym oraz oświadczenie o niezatrudnieniu lub niepozostawaniu w innym stosunku prawnym $\mathrm{z}$ adwokatem, radca prawnym, doradca podatkowym lub rzecznikiem patentowym.

Warto zauważyć, że przyznanie prawa pomocy może być cofnięte w całości lub w części, jeżeli się okaże, że okoliczności, na podstawie których je przyznano, nie istniały lub przestały istnieć (art. 249 p.p.s.a.). Trzeba także zwrócić uwagę na przepis art. 255 p.p.s.a.: „Jeżeli oświadczenie strony zawarte we wniosku, o którym mowa w art. 252, okaże się niewystarczające do oceny jej rzeczywistego stanu majątkowego i możliwości płatniczych oraz stanu rodzinnego lub budzi wątpliwości, strona jest obowiązana złożyć na wezwanie, w zakreślonym terminie, dodatkowe oświadczenie lub przedłożyć dokumenty źródłowe dotyczące jej stanu majątkowego, dochodów lub stanu rodzinnego”. Niezależnie od ewentualnego objęcia pomoca prawną art. $239 \S 1$ pkt 1 p.p.s.a. przewiduje rodzajowe zwolnienie z obowiązku uiszczenia kosztów sądowych w odniesieniu do szeregu spraw. Chodzi o skargi na działanie, bezczynność organu lub przewlekłe prowadzenie postępowania w sprawach: z zakresu pomocy i opieki społecznej, dotyczących statusu bezrobotnego, zasiłków oraz innych należności i uprawnień przysługujących osobie bezrobotnej, dotyczących chorób zawodowych, świadczeń leczniczych oraz świadczeń rehabilitacyjnych, ze stosunków pracy i stosunków służbowych, z zakresu ubezpieczeń społecznych, z zakresu powszechnego obowiązku obrony, udzielania cudzoziemcom ochrony oraz dotyczących dodatków mieszkaniowych.

Przywołując w tym kontekście zakres przedmiotowy nieodpłatnej pomocy prawnej, trzeba zwrócić uwage przede wszystkim na, wskazane w art. 3 u.n.p.p. w pierwszej kolejności, informowanie osoby uprawnionej do pomocy o obowiazującym stanie prawnym, o przysługujacych jej uprawnieniach lub o spoczywajacych na niej obowiązkach. Uświadomienie danej osobie jej sytuacji prawnej jest punktem wyjścia do dalszych działań, które ustawa ogranicza do wskazania tej osobie sposobu rozwiązania jej problemu prawnego i udzielenia pomocy

${ }^{17}$ Zgodnie z art. 245 p.p.s.a. prawo pomocy może być przyznane w zakresie całkowitym lub częściowym: w zakresie całkowitym obejmuje zwolnienie od kosztów sądowych oraz ustanowienie adwokata, radcy prawnego, doradcy podatkowego lub rzecznika patentowego, natomiast w zakresie częściowym obejmuje zwolnienie tylko od opłat sądowych w całości lub w części albo tylko od wydatków albo od opłat sądowych i wydatków lub obejmuje tylko ustanowienie adwokata, radcy prawnego, doradcy podatkowego lub rzecznika patentowego. Częściowe zwolnienie od opłat lub wydatków może polegać na zwolnieniu od poniesienia ułamkowej ich części albo określonej ich kwoty pieniężnej. 
w sporządzeniu projektu pisma (co ważne: z wyłączeniem pism procesowych w toczącym się postępowaniu przygotowawczym lub sądowym/sądowoadministracyjnym). Jeżeli osoba uprawniona do nieodpłatnej pomocy prawnej w konsekwencji ustalenia swojej sytuacji prawnej zechce wystapić na drogę sądowa, ustawa przewiduje pomoc ograniczajacca się do sporządzenia dla niej projektu pisma o zwolnienie od kosztów sądowych lub ustanowienie pełnomocnika z urzędu w postępowaniu sądowym lub ustanowienie adwokata, radcy prawnego, doradcy podatkowego lub rzecznika patentowego w postępowaniu sądowoadministracyjnym.

Reasumując, trzeba stwierdzić, że co do zasady wsparcie podczas stadium sądowego odbywa się na podstawie przepisów uzależniających zwolnienie od kosztów sądowych lub ustanowienie pełnomocnika z urzędu od indywidualnej i aktualnej sytuacji materialnej zainteresowanego, która zainteresowany musi wykazać przez złożenie stosownych oświadczeń zawierajacych nie tylko szczegółowe dane o jego majątku, dochodach i źródłach utrzymania, lecz także stanie rodzinnym. Właściwy sąd dokonuje oceny oświadczenia i stwierdza, czy poniesienie określonych kosztów jest w ogóle możliwe (p.p.s.a.) względnie prowadziłoby do uszczerbku koniecznego/niezbędnego utrzymania wnioskodawcy i jego rodziny (k.p.c., k.p.k., p.p.s.a.). Tymczasem nieodpłatna pomoc prawna adresowana jest do podmiotów wskazanych generalnie w art. 4 ustawy (można w tym widzieć swoiste ustawowe domniemanie trudnej sytuacji materialnej lub życiowej $\left.{ }^{18}\right)$. Oczywiście kryterium dochodowe ma znaczenie w odniesieniu do pierwszej ze wskazanych grup osób uprawnionych, tj. osób, którym w okresie 12 miesięcy poprzedzających zwrócenie się o udzielenie nieodpłatnej pomocy prawnej zostało przyznane świadczenie z pomocy społecznej i wobec których w tym okresie nie wydano decyzji o zwrocie nienależnie pobranego świadczenia. Uprawnione do świadczeń z pomocy społecznej są bowiem tylko osoby, których dochód leży poniżej ustalonych ustawowo granic (art. 8 ustawy z 12 marca 2004 r. o pomocy społecznej ${ }^{19}$ ) i występują wskazane w art. 7 tejże ustawy okoliczności uzasadniające udzielenie pomocy społecznej, a jednocześsnie osoby te nie są w stanie przezwyciężyć trudnej sytuacji życiowej za pomoca własnych zasobów majątkowych (por. art. 12 omawianej ustawy).

Co do pozostałych kategorii adresatów ustawy to ich sytuacja materialna (źródła utrzymania i wysokość dochodów, a także ewentualnie posiadany majątek) jest w istocie bez znaczenia. Dotyczy to zarówno posiadaczy ważnej Karty Dużej Rodziny, kombatantów, osób będących ofiarami represji wojennych i okresu powojennego, weteranów, jak i osób, których prawo do nieodpłatnej pomocy społecznej określono za pomoca kryterium wieku (osoby, które nie ukończyły 26 lat lub które ukończyły 65 lat), wreszcie osób, które w wyniku wystapienia klęski żywiołowej, katastrofy naturalnej lub awarii technicznej znalazły się w sytuacji zagrożenia lub poniosły straty. Oczywiście można się spodziewać, że z nieodpłatnej pomocy społecznej korzystać będą raczej osoby niezamożne (z tego też powodu rozważać można ocenę tej instytucji jako instrumentu zabezpieczenia społecznego), niemniej warto podkreślić, że ustawa nie

18 Por. uzasadnienie projektu ustawy, druk sejmowy, Sejm RP VII kadencji, nr druku: 3338.

19 Dz. U. 2004, Nr 64, poz. 593 ze zm. 
odnosi się do indywidualnej potrzeby, np. przez odwołanie się do kryterium możliwości finansowych danego zainteresowanego, a ogólnie określa grupy uprawnionych podmiotów.

Można zatem uznać, że jakkolwiek gwarancje prawa procesowego także realizuja cel socjalny, to ma on znaczenie drugoplanowe. Przede wszystkim chodzi bowiem o to, aby - niezależnie od aktualnej sytuacji materialnej każda osoba mogła wszcząc lub kontynuować postępowanie sądowe, a zatem o realizację prawa do sądu sensu stricto. Nieodpłatna pomoc prawna ma natomiast nieco odmienny cel i przeznaczenie. Chodzi przede wszystkim o realizację równego dostępu do sądu (prawo do sądu sensu largo), którego warunkiem jest świadomość prawna, uzyskana także w drodze informacji prawnej. Różnica nie dotyczy zatem tylko stadium, w którym określone wsparcie jest udzielane, ale przeznaczenia obu instytucji. Warto też zaznaczyć, że często sama informacja może okazać się wystarczająca, aby dana osoba mogła zrealizować swoje uprawnienie bez potrzeby wstępowania na drogę sądowa.

\section{NIEODPLATNA POMOC PRAWNA A POJĘCIE ZABEZPIECZENIA SPOŁECZNEGO}

Przed przedstawieniem pojęcia „zabezpieczenie społeczne” należy wskazać, że kwestia ta była już przedmiotem analizy ${ }^{20}$. W tym miejscu można tylko przypomnieć, że rozumienie treści tego pojęcia zmieniało się w czasie i zależało od stopnia realizacji postulatów zapewnienia obywatelom poczucia bezpieczeństwa socjalnego, przemian politycznych oraz społeczno-gospodarczych, a także rozwoju badań i dyskusji naukowych. Początkowo przyjmowano, że zabezpieczenie społeczne jest pewną idea, założeniem, zgodnie z którym na barki państwa spada troska o los swoich obywateli, którzy, w związku ze spełnieniem się ryzyk socjalnych, nie sa w stanie samodzielnie zapewnić sobie środków utrzymania, pomocy lekarskiej itp. ${ }^{21} \mathrm{~W}$ konsekwencji zabezpieczenie społeczne definiowano jako całokształt środków i działania instytucji publicznych, za pomoca których społeczeństwo stara się zabezpieczyć swych obywateli przed niezawinionym przez nich niedostatkiem, przed groźbą niemożności zaspokojenia podstawowych, społecznie uznanych za ważne, potrzeb ${ }^{22}$. Czesław Jackowiak postulował traktowanie zabezpieczenia społecznego jako pojęcia z zakresu polityki społecznej, pewnej idei, a nie określonej instytucji prawnej, i definiował je jako gwarancję zaspokojenia wszelkich potrzeb bytowych ludzi niezdolnych do pracy za pomocą różnych form świadczeniowych i technik administracyjno-

\footnotetext{
${ }^{20}$ Por. D. E. Lach, Pojęcie zabezpieczenia społecznego a przedmiot prawa socjalnego, w: Problemy zatrudnienia we wspótczesnym ustroju pracy. Księga jubileuszowa na 55-lecie pracy naukowej i dydaktycznej Profesora Włodzimierza Piotrowskiego, Poznań 2009.

${ }^{21}$ Por. I. Jędrasik-Jankowska, Ubezpieczenie spoteczne (chorobowe, rentowe i emerytalne). Zarys części ogólnej, Łódź 1987, s. 11-12.

${ }^{22}$ Por. J. Piotrkowski, Zabezpieczenie społeczne, w: E. Strzelecki (red.), Polityka społeczna. Materiały do studiów, Warszawa 1965, s. 28.
} 
-finansowych ${ }^{23}$. Z biegiem czasu rozumienie zabezpieczenia społecznego ewoluowało. Mianem tym zaczęto określać ogół urządzeń społecznych tworzonych przez państwo i gwarantujących obywatelom minimum egzystencji w obliczu wypadków losowych ${ }^{24}$ lub też ogół instytucji, zarówno prawnych, jak i pozaprawnych, zapewniających świadczenia w przypadku zdarzeń powodujących pozbawienie lub ograniczenie zdolności zarobkowania ${ }^{25}$. Inni autorzy definiowali je jako system świadczeń, do których obywatele maja prawo lub z których maja możność korzystania w wypadkach i na warunkach określanych odpowiednimi przepisami ${ }^{26}$, a środowiska nieprawnicze - wprost jako system podziału dóbr, nieodpłatny całkowicie lub częściowo, gwarantujący świadczenia z zakresu ochrony zdrowia, szkolnictwa różnych typów, innych urządzeń socjalnych, kulturalnych, gospodarki mieszkaniowej itp. ${ }^{27}$

Dziś należy uznać, że zabezpieczenie społeczne w sensie prawnym stanowi całość instytucji i urządzeń prawnych, których działalność ma na celu zabezpieczanie losu i bytu jednostki w sytuacji ziszczenia się niekorzystnych sytuacji, zwanych ryzykiem socjalnym. Jako „tradycyjne” ryzyka socjalne literatura wskazuje: dożycie wieku emerytalnego, trwała lub okresową niezdolność do pracy, śmierć żywiciela, niezdolność lub niemożność świadczenia pracy, wypadek przy pracy lub chorobę zawodowa, utratę zdrowia („niezdrowie”), bezrobocie, niedostatek dochodu w rodzinie i trudne sytuacje życiowe ${ }^{28}$. Trzeba jednak zastrzec, że zarówno de lege lata, jak i de lege ferenda wciąż formułuje się nowe ryzyka socjalne. $Z$ jednej strony należy wskazać np. na ryzyko niewypłacalności pracodawcy lub „niewypłacalności” dłużnika alimentacyjnego, a także ponoszenie wydatków związanych $\mathrm{z}$ wychowaniem dzieci (program $500+$ ), z drugiej natomiast - np. zagrożenie odejściem żywiciela rodziny jako pochodną rozpadu życia rodzinnego (rozwód).

Można przy tym uznać, że jest w istocie bez znaczenia, jaką techniką zabezpieczenia społecznego posługuje się dana instytucja (czy jest to ubezpieczenie społeczne, zaopatrzenie, powierniczy zarząd, pomoc społeczna), jaka jest jej forma prawna i na podstawie jakiego tytułu potrzebujący otrzymuje świadczenie. Innymi słowy, to funkcja danej instytucji lub urządzenia prawnego, jeśli jest nią realizacja idei zabezpieczenia społecznego, decyduje o jej przyporządkowaniu do zabezpieczenia społecznego.

Powstaje w związku z tym pytanie, czy w przypadku świadczeń nieodpłatnej pomocy prawnej można mówić o realizacji idei zabezpieczenia społecznego rozumianego jako zaspokojenie potrzeb bytowych. Prima facie trzeba by uznać,

${ }^{23}$ Tak C. Jackowiak, w: W. Jaśkiewicz, C. Jackowiak, W. Piotrowski, Prawo pracy. Zarys wykładu, Warszawa 1970, s. 349.

${ }^{24}$ Por. W. Szubert, Zagadnienia prawne ubezpieczenia społecznego. „Państwo i Prawo” 1957, z. 1, s. 46-47; idem, Studia z polityki społecznej, Warszawa 1973, s. 229.

${ }^{25}$ Por. K. Kolasiński, Rozstrzyganie sporów o świadczenia z zabezpieczenia spotecznego, Warszawa 1978, s. 14.

${ }^{26}$ Tak A. Rajkiewicz, Zabezpieczenie społeczne, w: A. Rajkiewicz (red.), Polityka społeczna, Warszawa 1979, s. 439.

${ }^{27}$ Tak B. Minc, Ekonomia polityczna socjalizmu, Warszawa 1963, s. 535.

${ }^{28}$ Por. J. Jończyk, Prawo zabezpieczenia spotecznego. Ubezpieczenia społeczne $i$ zdrowotne, bezrobocie i pomoc spoteczna, Zakamycze, Kraków 2001, s. 14-21. 
że pomoc prawna nie ma charakteru bytowego, co sugerowałoby odpowiedź odmowna. Z drugiej jednak strony można by podnieść, że - bezdyskusyjnie zaliczany do systemu zabezpieczenia społecznego - system opieki zdrowotnej gwarantuje przecież nie tylko świadczenia ratujące życie, ale także i takie, które trudno uznać za służące zaspokojeniu podstawowych potrzeb bytowych (np. leczenie uzdrowiskowe). Czy zatem potrzeba otrzymania pomocy prawnej, nie będąc oczywiście potrzebą bytową w rozumieniu zabezpieczenia egzystencji, może być współcześnie uznana za ważną potrzebę społeczną zaspokajana w ramach systemu zabezpieczenia społecznego?

Wydaje się, że za uznaniem nieodpłatnej pomocy prawnej za instrument zabezpieczenia społecznego przemawiaja co najmniej dwa ważkie argumenty. Po pierwsze, należy zauważyć, że obecnie potrzeba dostępu do porady prawnej jest niewątpliwe jedną z potrzeb uznanych społecznie za ważne. Świadczy o tym sam fakt wprowadzenia instytucji nieodpłatnej pomocy prawnej w reakcji na, rozmaicie artykułowane, oczekiwania społeczne. Stanowi ona przy tym element konstytucyjnego prawa do sądu (art. 45 Konstytucji RP), którego realizacja nie może być uzależniona od sytuacji materialnej jednostki, oczekującej „sprawiedliwego i jawnego rozpatrzenia sprawy bez nieuzasadnionej zwłoki przez właściwy, niezależny, bezstronny i niezawisły sąd".

W literaturze podkreślono, że podstawowym założeniem realizowanym w prawie do sądu jest konstytucyjna równość wobec prawa ${ }^{29}$. W tym też kontekście warto przywołać uzasadnienie projektu ustawy, w którym wskazano, że: „obywatele nie mają zapewnionego równego dostępu do porady prawnej na etapie przedsądowym. Jeśli chodzi o porady bezpłatne, większe możliwości w tym zakresie posiadają mieszkańcy dużych ośrodków miejskich, a zwłaszcza ośrodków uniwersyteckich. Wiąże się to obszarem działalności organizacji pozarządowych specjalizujących się w poradnictwie prawnym. Osoby posiadające wystarczające środki finansowe mogą uzyskać pomoc prawna, $\mathrm{w}$ tym poradę prawna, od profesjonalisty, tj. adwokata albo radcy prawnego. Brak jest natomiast mechanizmów umożliwiajacych uzyskanie dostępu do tego rodzaju usług osobom, których stan majątkowy nie pozwala pokryć kosztów porady prawnej na wolnym rynku. Brak mechanizmu umożliwiającego uzyskanie nieodpłatnie przez osoby ubogie porady prawnej udzielonej przez profesjonalistę, a także rozproszenie nieodpłatnego poradnictwa prawnego wskazuje na nierówny dostęp obywateli do usług prawniczych. Konsekwencją tego może być uznanie, że państwo nie zapewnia swym obywatelom równego dostępu do wymiaru sprawiedliwości. [...] Projektowany system nieodpłatnej pomocy oraz nieodpłatnej informacji prawnej ma zatem doprowadzić do stworzenia mechanizmów umożliwiajacych dostęp do uzyskania porady prawnej przez osoby fizyczne, które z uwagi na swój status materialny lub sytuację życiową nie mają możliwości uzyskania profesjonalnej pomocy prawnej, a wszystkim osobom fizycznym zagwarantować dostęp do informacji prawnej”. Podkreślając znaczenie równego dostępu do wymiaru

${ }_{29}$ Por. M. Grego-Hoffmann, Rola petnomocnika $w$ postepowaniu sqdowoadministracyjnym, Lex 2012. 
sprawiedliwości, stanowiącego szczególną formę ogólnej zasady równości, należy przy tym zaznaczyć rozróżnienie pomiędzy instytucjami prawa procesowego, służącymi wsparciu osób w trudnej sytuacji materialnej, i - poprzedzająca przecież ewentualne wstapienie na drogę sądową - zindywidualizowana poradą prawną, pomagającą zorientować się osobie uprawnionej w jej sytuacji prawnej.

Po drugie, trzeba mieć na uwadze, że dostęp do porady prawnej bardzo często warunkuje możliwość skorzystania z gwarantowanych ustawowo świadczeń zabezpieczenia społecznego. Skomplikowanie systemu, wielość, obszerność i nieustanna zmiennośćc ${ }^{30}$ właściwych aktów normatywnych, bogate i - bywa - rozbieżne orzecznictwo powoduja, że osoba uprawniona pozbawiona profesjonalnego wsparcia często nie jest w stanie skutecznie dochodzić należnych jej świadczeń. W doktrynie prawa konstytucyjnego podkreśla się, że prawo dostępu do sądu to „możliwość zwrócenia się w każdej sytuacji (sprawie) do sądu z żądaniem określenia (ustalenia) statusu prawnego jednostki, w sytuacjach nie tylko zakwestionowania lub naruszenia jej praw i wolności, lecz również $\mathrm{w}$ sytuacjach odczuwanych przez nią niejasności, niepewności, a zwłaszcza obawy wystapienia takiego naruszenia" ${ }^{31}$. Warto także zauważyć, że odnoszac się do kryterium fakultatywności jako cechy wyróżniającej pomoc społeczna jako jeden z instrumentów zabezpieczenia społecznego, Jan Jończyk wskazywał, że współcześnie traci ono na znaczeniu właśnie wobec powszechności prawa do sądu i prawa do rzetelnego procesu ${ }^{32}$.

W tym także kontekście można nadto przywołać, zaproponowane już wcześniej ${ }^{33} \mathrm{w}$ nawiązaniu do opracowań doktryny niemieckiej ${ }^{34}$, stopniowanie ryzyka socjalnego. W myśl tej koncepcji ryzyko pierwszego stopnia dotyczy niebezpieczeństwa pozostania poza systemem zabezpieczenia społecznego, mimo obiektywnie istniejącej potrzeby otrzymania pomocy bytowej wobec niemożności zapewnienia samodzielnie i własnym staraniem należytego poziomu egzystencji. Natomiast ryzyko drugiego stopnia odnosi się tylko do osób objętych systemem i oznacza wystapienie w stosunku do nich takiego zdarzenia losowego, z którego ziszczeniem się przepisy prawa wiążą obowiązek udzielenia świadczeń z systemu zabezpieczenia społecznego (ryzyko jako prawna konkretyzacja zdarzeń losowych), wraz z analiza, czy w stosunku do danego zdarzenia losowego nie zachodzą okoliczności, które wyłączałyby obowiązek spełnienia/sfinansowania świadczenia.

30 Tytułem przykładu przywołać można regulację dotyczącą zawieszenia prawa do emerytury w przypadku kontynuowania zatrudnienia po nabyciu prawa do emerytury, por. D. E. Lach, Realizacja nabytych $i$ niekonstytucyjnie zawieszonych praw emerytalnych (kilka uwag na tle wyroku Trybunału Konstytucyjnego w sprawie K 2/12), w: Studia i Analizy Sadu Najwyższego, t. 7, Warszawa 2014

31 Por. P. Sarnecki, Omówienie art. 45, w: L. Garlicki (red.), Konstytucja Rzeczypospolitej Polskiej. Komentarz, t. 3, Warszawa 2003, s. 1-2; także B. Banaszak, Porównawcze prawo konstytucyjne wspótczesnych państw demokratycznych, Lex 2012.

32 Por. J. Jończyk, op. cit., s. 55.

33 Por. D. E. Lach, Zasada równego dostępu do świadczeń opieki zdrowotnej, Warszawa 2011, s. 93.

${ }^{34}$ Por. H. F. Zacher, Abhandlungen zum Sozialrecht, Heidelberg 1993, s. 34-35. 
Na tym tle można by uznać, że nieodpłatna pomoc prawna służy nie tylko osobom „zabezpieczonym społecznie”, wspierając je w dochodzeniu należnych świadczeń. Jej celem może (powinno) być także pomaganie osobom uprawnionym we włączeniu ich do systemu zabezpieczenia społecznego. Nie można bowiem nie uwzględniać tej istotnej okoliczności, że np. wielość podstaw zatrudnienia ma swoje konsekwencje nie tylko w odniesieniu do uprawnień prawnopracowniczych, ale także powstawania i ewentualnego zbiegu tytułów ubezpieczeń społecznych. W obliczu migracji zarobkowych oraz koordynacji systemów zabezpieczenia społecznego państw członkowskich UE problematyczne jest często ustalenie ustawodawstwa właściwego (np. w odniesieniu do pracowników delegowanych).

\section{PODSUMOWANIE}

Teza, zgodnie z którą nieodpłatna pomoc prawna może być uznana za jeden z instrumentów zabezpieczenia społecznego, może być oceniana jako zbyt daleko idąca. Przedmiotem tej pomocy nie jest przecież zabezpieczenie bytu jednostki lub rodziny w sytuacji ziszczenia się niekorzystnych zdarzeń losowych. Mając jednak na uwadze możliwość stopniowania ryzyka socjalnego, zakres przedmiotowy oraz podmiotowy tejże pomocy, wydaje się, że można znaleźć dobre argumenty przemawiajace za zaakceptowaniem takiej tezy. Nieodpłatna pomoc prawna służy przecież w pierwszej kolejności uświadomieniu jej beneficjentów - osób w trudnej sytuacji materialnej lub życiowej - co do ich sytuacji prawnej, co jest punktem wyjścia do dochodzenia przez nich swoich praw. Wobec coraz większej komplikacji systemu zabezpieczenia społecznego ogólne i z konieczności zazwyczaj ogólnikowe informacje, zamieszczane np. na stronach internetowych Zakładu Ubezpieczeń Społecznych, Narodowego Funduszu Zdrowia, ośrodków pomocy społecznej i pomocy rodzinie, urzędów pracy, Państwowej Inspekcji Pracy i innych podmiotów wykonujących zadania z zakresu zabezpieczenia społecznego, okazują się często niewystarczające lub wręcz niezrozumiałe. Dla zrealizowania uprawnień wynikających $\mathrm{z}$ udziału w systemie zabezpieczenia społecznego, czy też dla włączenia do tego systemu, potrzebna jest zatem informacja zindywidualizowana i skonkretyzowana, dająca podstawę do podjęcia decyzji o ewentualnym wkroczeniu na drogę sądową. Taki jest cel nieodpłatnej pomocy prawnej. Czy w rzeczywistości spełni ona tę funkcję, czas pokaże.

dr hab. Daniel E. Lach

Profesor Uniwersytetu im. Adama Mickiewicza w Poznaniu lach@amu.edu.pl 
FREE LEGAL ASSISTANCE AS AN INSTRUMENT OF SOCIAL SECURITY

Sum mary

The subject of the study is an analysis of the regulations of the Act of 5 August 2015 on Free Legal Assistance and Legal Education with a purpose of evaluating if free of charge legal assistance can be considered to constitute an instrument of social security. The rules of providing free legal assistance, including the scope of this assistance and persons entitled to receive it, as well as the organisational and financing solutions are presented and compared with the regulations of the procedural law on the exemption from court fees and state-funded legal aid fees. The term 'social security' is also discussed and analysed and against its background the regulations of the Act of 5 August 2015 are analysed. 